\title{
Exploring the Role of Cultural Teaching in EFL College Programs: An Introspective Study
}

\author{
Hamad Aldosari, Ismail Alrefai \\ English Department, Faculty of Languages and Translation, King Khalid University, Abha, Saudi Arabia \\ Email address: \\ Hsaldosari@kku.edu.sa (H. Aldosari)

\section{To cite this article:} \\ Hamad Aldosari, Ismail Alrefai. Exploring the Role of Cultural Teaching in EFL College Programs: An Introspective Study. International \\ Journal of Language and Linguistics. Vol. 8, No. 4, 2020, pp. 174-184. doi: 10.11648/j.ijl1.20200804.18
}

Received: July 24, 2020; Accepted: August 10, 2020; Published: August 18, 2020

\begin{abstract}
Culture-embedded teaching is integral to teaching foreign languages. In Saudi higher education, the cultural aspects of the target language is poorly integrated in foreign language education due to rigid doctrinaire ideologies. This study, using a survey research design, aimed to introspect the perceptions of EFL instructors about culture and literature teaching in EFL college programs, particularly in Saudi Arabia. The study also explored the perceptions and attitudes of EFL college English language instructors concerning the integration of culture in English language education programs. Utilizing a descriptive research methodology, the researchers made use of questionnaires and interviews to tap into the perceptions of faculty responsible for teaching English as a foreign language courses in the EFL program of the College of Languages and Translation, King Khalid University. The survey and interviews also examined the EFL teachers' attitudes towards the integration of literature teaching in English education. The findings showed that EFL instructors were concerned with explicit teaching of cultural issues through literature as an excellent source of culture-laden material for foreign language learning. However, due to meagre literature teaching, the current program is short of presenting adequate culture content integration. Barriers perceived include over-use of indigenous cultural and Islamic themes that interfere with proper teaching of the target language. Findings also revealed that teachers entertained positive attitudes toward integrating culture in language education through using a variety of methods and techniques. Pedagogical implications advocate the importance of integrating culture into foreign language teaching courses, especially in the literature curriculum stream as well as integrating real-life conversational excerpts for teaching culturally-laden content in listening and speaking courses. Suggestions for further research topics on culture integration in ELT are presented eventually.
\end{abstract}

Keywords: Culture, Culture Education, Literature Education, Saudi Universities

\section{Introduction and Background}

Learning a foreign language entails a lot of learning from the target foreign culture, since "learning new languages opens the minds of students to other people's lifestyles and "increases opportunities for cross-cultural understanding" (p. 105) [1]. Obviously, culture has time and again been integrated into foreign language classes [1-8]. However, the teaching of culture, or acculturation, does not equate to the transmission of information about the population of the community or country whose language is targeted by learning, even though this type of knowledge is an important element in the foreign language education program [9]. This is true simply because culture is just a fountain of details and experiences that can be utilized in foreign language education if necessary.

In fact, learning a foreign language cannot be reduced to only learning communication in the target language; it involves discovering how much limberness the target language allows students to handle grammatical forms, sounds and word meanings individually and contextually. As well, foreign language education should teach learners how to reproduce or even circumvent the socially (un) accepted norms both in their own culture or in the target culture, which entails some kind of intercultural awareness integrated in the foreign language curriculum.

In this sense, [10] aptly perceived that foreign language learners in the past who were taught after a GrammarTranslation method having in their minds the goal of foreign language learning as the study of foreign literature. Therefore, 
they were short of learning about the target culture but through the narrow window of literature. Over the past decades, many researchers [3, 11-14] made many attempts to ground foreign language education theory into a universally accepted set of principles that cover the learners' socioaffective, cognitive and psychomotor needs in order to make "the foreign culture less threatening and more accessible to the language learner" (p. 224) [15].

In this vein, too, with the rise of the audiolingual method, [2] accentuated the significance of culture not only for the sake of literature teaching but also for the overall learning of foreign languages. Brooks's innovative work [2] actually led to a change of focus from the teaching of social studies in the medium of language teaching, or via an integrated approach or content-based teaching approach as described by Oxford [16] to an anthropological approach deeply grounded in the study of culture. Therefore, acculturation should be integrated into the language curriculum for 'developing an awareness of, and sensitivity towards, the values and traditions of the people whose language is being studied' ( $p$. 26) [17].

Subsequently, cultural awareness needs to be nurtured by teaching the target culture inclusively to develop foreign language students' awareness of the underlying beliefs and values inherent in the social system where the language is used by its native speakers (p. 242) [18] - an approach that has been adopted in communicative teaching pedagogies. More notably, integrating the target culture in the foreign language-learning curriculum has been advocated to show that learning this culture should place us towards a certain vision of the world through building a cognitive framework composed of a series of comprehensive and non-quantifiable assumptions about how the world is viewed by others (p. 242) [18]. But then again this cognitive framework should be further nurtured "through the very use of language, the most visible and available expression of culture" (p. 33) [19].

Regardless of its importance, the teaching of foreign languages has been discussed through publications that reflect the culture of this language, and attitudes towards the teaching of literature have prevented it from finding its place in language programs generally in certain communities such as Saudi Arabia. Previous research has found little evidence to affirm the usability of literature and the use of literature as an effective medium to teach culture in foreign language programs, which warrants more research, endeavors to ensure the viability of literature teaching as an effective means of acculturation and foreign language education.

Given the paucity in research which examines EFL teacher's views on cultural learning, or about cultural teaching in TEFL generally, a number of studies have been undertaken to gain a better understanding of the extent to which EFL educators are familiar with the role of culture in language learning and how it affects its pedagogy. For instance, Lessard-Clouston conducted an introspective study in which 16 Chinese EFL teachers were interviewed to introspect their views on the teaching of culture besides foreign language education [20]. The perceptions of the interviewees indicated that the teaching culture could make language education a more fruitful and effective experience, but there was a need for a greater understanding of how to integrate culture in the EFL curriculum. Similarly, Prodromou did another study on 300 Greek language students and found that more than half of the informants thought that native language teachers should have sufficient knowledge of the students' native language and its culture in order to be able to acculturate them into the target culture [21]. Moreover, Duff and Uchida conducted a case study on four English teachers in another research that showed a great deal of complexity in the teachers' socio-cultural identities [22]. This case study also showed lack of awareness on the part of the teachers that they indirectly communicated cultural messages to their students.

Notwithstanding the results of these studies, there is still a commonly believed deficiency in research evidence on how foreign language educators perceive the integration of culture in the language curriculum and how these beliefs are reflected in their teaching.

\section{Context of the Problem of the Study}

Understanding the integration of culture in the target culture classroom by teaching English literature can be important and essential. Nevertheless, the use of literature as a medium of acculturation or integrating culture education into foreign language teaching in Arab universities is not easy to adjust in EFL contexts. In this line, teacher training in foreign acculturation experience, limited knowledge of the target culture, lack of appropriate pedagogical methods and apposite cultural content, lack of time and fear of teaching disputes on world views as a barrier to cultural and literature education are examples of impediments to acculturation [2327]. Problems pointed out in relevant literature of relevance to cultural teaching indicates that acculturation or cultural education is a very broad pedagogy and that many methods are used to bring about changes in the concept of "culture" [28].

Extant research focuses on 'non-native English speaking' teachers of English in English education programs [29-34]. Such research raises many questions about the ownership of English and the 'privileged position' of the inner circle of English-speaking countries such as Britain, USA, Canada, Australia, and New Zealand [35].

In this context, Harumi [5], citing Kachru (p. 11) [36], claims that the globalization of English not only supports the 'Englishization' of other world languages, but also the 'nativization' of English. Harumi also argues that the pervasive dominance of English as a lingua franca, irrespective of dialectical differences, has deprived Englishspeaking peoples of the exclusive possession of the language, because at the present time, English no longer a vehicle of Western culture; "it only marginally carries the British and American way of life" (p. 67) [37].

This study aims to identify the barriers to cultural education involved in the teaching of English literature for 
EFL students at Saudi Arabian universities as perceived by EFL college educators and students. Therefore, the problem of the study is summarized in the following research questions:

1. What are the perceptions of EFL college teachers about culture and literature teaching in EFL college programs?

2. What are the attitudes of EFL college teachers towards culture-embedded literature teaching?

3. How can culture education be embedded in literature classes?

\section{Theoretical Framework}

The role of linguistic competence and socio-cultural competence in foreign language pedagogy has not been discussed yet as a crucial factor in intercultural communication [38]. Some authors suggested that an incorrect conceptualization of culture was conducive to less integration of culture in the foreign language curriculum. For instance, Lafayette expounded that this under-representation or lack of integration of culture in the language curriculum content was attributed to limited culture together teaching or lack of foreign language teachers who are quite familiar with the target culture [39]. Byram and Wagner have saliently observed that "While proclamations in favor of foreign language education and its effects on international or intercultural understanding are by no means rare" (p. 141) [40]. One more reason is that foreign language learning requires substantial foreign culture learning, now that "learning new languages opens students' minds to the ways of other peoples and increases the opportunities for crosscultural understanding" (p. 105) [1]. In addition, in foreign language teaching settings in non-native countries and in acquisition settings in native-speakers' natural environments, linguistic competence incorporates an implicit, yet equally significant portion of the acquisition of cultural awareness skills, knowledge of self and others both in interpersonal and inter-societal interactions [41]. Literature on language and acculturation in the target language environment is abundant in research and theory that explain how acculturation builds up to the development of language learning [42].

Briefly put, it can be extrapolated that acculturation to the target language culture involves some level of intercultural communication competence - a process that, in turn, involves linguistic competence and extra-linguistic competence, including the mental representations of language and its pertinent culture and their implementation in the social context, governed by the 'grammars' of socio-cultural competence [43]. The history and development of theory and practice in acculturation in relation to second language acquisition or foreign language learning has evolved in the field of foreign language teaching for more than six decades now. Coperías-Aguilar showed the inception of such theories started with the introduction and revision of different views about models of linguistic competence as a function of enculturation and acculturation [42].

Appropriate integration of culture teaching into the teaching of foreign languages can inform not only the pedagogical practices and curricular designs, especially in higher education settings, as well as improve learners' linguistic competence and cultural learning. In this regard, Damen contends that teaching about intercultural communication can contribute to the development of intercultural sensitivity and intercultural communication competence [25]. This can be done through providing language educators with guidance to incorporate culturalgeneral and cultural-specific content in the foreign language class.

Researchers suggested that for incorporating culture in language education, a combination of intercultural knowledge, intercultural skills and intercultural attitudes should be introduced as the basis for developing learners' intercultural competence. In addition, the goals of language education should include items that provide for on-going development of these three components, and consequently, subject competences should be emphasized to develop knowledge, skills, and attitudes in foreign language curriculum [44].

Language learning, assuming culture learning, too, is viewed as a process of concurrent acquisition of both linguistic knowledge and sociocultural knowledge, respectively integrating linguistic competence and cultural competence for foreign language learners to be able to use a foreign language competently [45]. This process of languacultural acquisition regards language as

"a primary symbolic medium through which cultural knowledge is communicated and instantiated, negotiated and contested, reproduced and transformed" (p. 339) [46].

Liu indicates that intercultural communication in the EFL context is defined as the person's abilities to use the target language flexibly, effectively and appropriately in IC by negotiating meanings of the interlocutors in a particular communicative event [47]. The meaning and negotiation is often affected by the student's cultural knowledge, in addition, a very important part of that knowledge is from the teacher and selected teaching materials in class. In addition, Liu et al. state that "culture is not instinctive or innate; culture is learned, communication and culture are inseparable." (p. 316) [48].

On the other hand, Coperías-Aguilar believes that nonnative teachers are preferred in developing the students' competence by connecting between their own culture and other cultures in addition to awakening their curiosity about differences in cultures [42]. Hence, Coperías-Aguilar emphasizes that the best teacher is not a native or non-native speaker, however, it is the one who helps students connect between their culture and other cultures in addition to awakening the learners' curiosity about cultural differences and otherness [42]. Alptekin states that bilinguals who are interculturally aware serve better than monolingual native speakers in instruction and instructional material should comprise international and local contexts which are related to the learners' lives [49].

Arévalo-Guerrero believes enhancing ICC can be through 
learning activities and discussions of cultural values, stereotypes and cultural misunderstanding [50]. Discovering one's culture and identifying the differences between other cultures require certain levels of tolerance and willingness to reflect critically about prejudices and assumptions. In such activities, students learn as they look at their own cultural environment from an outside perspective, this enables them to value and accept differences within cultures including their own. In other words, considering peoples' cultural aspects is effective in communication.

On the contrary, students' cultural learning may not result in obtaining tolerance, understanding or empathy. Actually, they may experience stages of ethnocentrism such as reversal and defense and may perceive the culture through stereotypes. However, in the process of developing intercultural sensitivity and competence, these are possible outcomes. Chen and Young indicate that foreign language study does not result in intercultural competence. Thus, communicative competence does not happen naturally, it is learned [51].

Cultural competence is now generally recognized as a goal in foreign language learning and teaching and knowledge about socio-linguistic rules is necessary in instruction. Learners typically find it hard to endure cultural differences such as beliefs, values and ways of communicating. In addition, people tend to view others form a personal perspective which results in stereotyping in judgements. Stereotyping notions in culture and race cause impedes empathy. Ethnocentrism is a tendency to judge people unconsciously by the standard of his/her group and his/her own customs. People tend to position themselves at the center of the universe, judge others from their personal perspective, and usually view themselves and culture as the best.

However, when empathy is developed and reciprocal, we can see matters from the others point of view and allowing the existence of differences between cultures is important for easy IC. The ability to speak the language and the knowledge of the foreign culture in how it is similar or different from ours results in effective communication with strangers. A competent intercultural communicator realizes and understands their own cultural identities, which reflects their overall perceptions, values and views. Thus, being aware of other culture's communication styles is an essential component of IC.

Teaching Cultural Awareness in Language Education Programs

Cultural awareness is a significant feature of intercultural communicative communication that develops which language learners acquire during all phases of education from the elementary school to tertiary education so as to help learners understand other cultures and adapt their behavioral modes and attitudes to cultural variations in a more empathic fashion. In this sense, Bhawuk and Brislin expound.

"to be effective in another culture, people must be interested in other cultures, be sensitive enough to notice cultural differences, and then also be willing to modify their behavior as an indication of respect for the people of other cultures" (p. 416). [52]

A predictable consequence of learning about the target culture is the development of one's intercultural awareness and their understanding of their own cultures. Therefore, Paige elucidates this finding about the pedagogy of cultural learning as follows:

"intercultural education requires learners to reflect upon matters with which they have had little first-hand experience which includes highly personalized behavior and affective learning, self-reflection, and direct experience with cultural differences" (p. 3). [53]

Paige further expounds that cultural learning repeatedly maintains learners in a state of healthy doubt that creates some sort of cultural relativism where learners are cautious to make judgments about others from different cultures due to the development of their sophisticated self-awareness. He clarifies this point by suggesting that...

"Human beings seem little inclined to reflect consciously and critically on their own culture or alternatives to it and they do not routinely test their assumptions about personal qualities they feel they possess" (p. 17) [53].

For intercultural experience to create this level of selfreflectiveness and self-awareness, individuals need to pass forcibly through highly intense cultural experiences. As such, cultural awareness forms a foundational requirement for inducing intercultural sensitivity and intercultural competence as it sets the basics of cultural learning in the context of a foreign language education class [54].

The relationship between language and culture are so sophisticated that their precincts are fuzzy at the ends. Therefore, it is hard to perceive or introspect the assumptions and expectations held by foreign language learners about the target culture and the need to learn it side by side with the foreign language [55]. Even though that language learning is a process of correspondingly cultural learning, that is, 'through language teaching, it is inevitable that culture is taught implicitly' (p. 212) [56]. To show this relationship more prominently, literature teaching as a medium of acculturation will help in this process. Unlike the concepts of Brooks [2], a number of researchers recognized the importance of using literature to articulate a particular language culture in more contextualized ways.

In this regard, Cai proposed that the fundamental purpose of integrating the target language literature in the language curriculum is to challenge the prevailing ideas, values and experiences of the target culture that are under-represented in the language curriculum [57]. Culture teaching, or acculturation, leads to the affirmation and appreciation of cultural diversity, promotes sensitivity to social disparities, and 'encourages transformation of self and society'. (p. 134) [57]

In turn, some researchers observed that the ultimate goal of integrating culture through literature teaching is to induce cultural learning [58-68]. This means that when foreign language learners are exposed to multicultural literary texts, this will inspire them to learn to read and write, and to compare and analyze the attitudes and values in the West and 
the East and this learning will strengthen their attitudes and motivations to learn foreign languages. When students explore new multicultural themes or topics through literature, they can relate the various conflicts and cultural issues latent in literary discourse such as that of fiction or non-fiction literary works. The texts partially excerpted or fully integrated in literature courses cannot be 'considered for their aesthetic' values only, but should be considered for their pedagogical implications as well (p. 24) [69].

\section{Research Method}

Researchers in this study employed the descriptive method. The descriptive research design was contrived to glean both quantitative data from the Likert scale items as well as qualitative data from the open-ended section of the questionnaire to "use questionnaires to collect data from participants in a sample about their characteristics, experiences, and opinions in order to generalize the findings to a population that the sample is intended to represent." (p. 289) [70]. This research method can provide a basis for decisions that are significant for the evaluation of current educational practices [71].

\subsection{Instruments}

To introspect the perceptions, attitudes towards target culture and perceptions about the teaching of English literature, a questionnaire for EFL college teachers in a Southern Saudi university was administered to a randomly selected sample of faculty for completing. An open-ended interview script was also conducted. The questionnaire was designed to introspect the views of teachers about three significant aspects of literature teaching: (1) perceptions about the importance of foreign language education and literature education in EFL classrooms; (2) participants' perceptions of and attitudes towards culture teaching in the current literature curriculum; and (3) methods and techniques of integrating literature education in the EFL curriculum in Saudi Arabian universities.

Now that the survey study was designed to introspect EFL instructors views about the use of literature as a medium and method for EFL cultural education, independent variables such as teachers' experience and the nationality were excluded as decisive factors. However, given the lack of similar studies, the survey study here serves as a source of information. The questionnaire included both a Likert answer option and room for an open answer to some questions.

\subsection{Questionnaire Validity}

The questionnaires were sent out to nine professors in English literature and applied linguistics to evaluate interrater validity. Feedback indicated the instruments were valid enough to collect the data they were designed to gather.

\subsection{Questionnaire Reliability}

The EFL teachers' questionnaire form was given to 25 faculty members and lecturers to calculate its reliability, using a test-retest procedure. The reliability of the faculty questionnaire form was computed by employing the KuderRichardson formula (21). The reliability co-efficient computed for the survey items was 0.87 - a value high enough to make the survey reliable for data collection.

\subsection{Participants}

Twenty-five English-speaking teachers affiliated to a Southern Saudi university participated in this. There were twenty teachers who had taught for more than 5 years, and their previous teaching experience ranged from 5 to 15 years either in Saudi Arabia or elsewhere. The other five of the participant faculty had more than 15 years of TEFL experience. Of these, $40 \%$ had doctorates, and the other $60 \%$ had Mas in linguistics, applied linguistics, literature, and TESOL pedagogy. Overall, the participant teachers taught at universities, some taught at junior colleges (two years postsecondary institutes) and some came from a broad spectrum of educational institutions ranging from high school to university and had extensive experience in ESL and EFL pedagogy.

\section{Results}

Highlights of survey findings

The participant teachers responded to the survey questions on a five-point scale, from 'Strongly agree' (scored 1) to 'Strongly disagree' (scored 5). Responses of 1 and 2 were merged to indicate agreement, and responses of 4 and 5 were merged to indicate disagreement while responses with 3 were regarded as neustral. Below is an analysis of the three sections of the questionnaire.

As such, the open-ended responses addressed a remarkable range of examples and ideas. The first five questions dealt with informants' attitudes towards the teaching/learning of culture as part of their language classes.

Table 1. Frequencies, percentages, weighted percentages, and Chi ${ }^{2}$ for section 1.

\begin{tabular}{|c|c|c|c|c|c|c|c|c|}
\hline \multirow{2}{*}{ Items } & \multicolumn{2}{|c|}{ Agree } & \multicolumn{2}{|c|}{ Neutral } & \multicolumn{2}{|c|}{ Disagree } & \multirow{2}{*}{ Weighted percentage } & \multirow{2}{*}{$\mathrm{Chi}^{2}$} \\
\hline & Freq & $\%$ & Freq & $\%$ & Freq & $\%$ & & \\
\hline 1 & 10 & 41.8 & 11 & 42.9 & 4 & 14.1 & 2.291066 & $* 67.33$ \\
\hline 2 & 14 & 53.2 & 7 & 32.7 & 4 & 14.1 & 2.340058 & $* 63.24$ \\
\hline 3 & 17 & 60.8 & 6 & 31.1 & 2 & 8.1 & 2.527378 & $* 145.52$ \\
\hline 4 & 20 & 83.6 & 4 & 25.1 & 1 & 2.6 & 2.697406 & $* * 263.82$ \\
\hline 5 & 14 & 53.2 & 6 & 31.1 & 5 & 16.7 & 2.080692 & $* 4.36$ \\
\hline
\end{tabular}

* significant at $0.01 ; *$ significant at 0.05 . 
Table 1 above demonstrates the $\mathrm{Chi}^{2}$ values for the five items in this section, significant at 0.01 , which suggests that most participants agreed to the items of this section in a positive manner. This finding reveals that English language teachers greatly perceive the importance to incorporate culture in their teaching of English through literature.

While very few teachers disagreed or were neutral to the items on this section, the overall responses indicated that some teachers still continue to be dubious about the worth of integrating culture in the EFL curriculum.

Table 2. Frequencies, percentages, weighted percentages, and $C h i^{2}$ for teachers' responses on section two of the questionnaire.

\begin{tabular}{|c|c|c|c|c|c|c|c|c|}
\hline \multirow{2}{*}{ Items } & \multicolumn{2}{|c|}{ Agree } & \multicolumn{2}{|c|}{ Neutral } & \multicolumn{2}{|c|}{ Disagree } & \multirow{2}{*}{$\begin{array}{l}\text { Weighted } \\
\text { percentage }\end{array}$} & \multirow{2}{*}{$\mathrm{Chi}^{2}$} \\
\hline & Freq & $\%$ & Freq & $\%$ & Freq & $\%$ & & \\
\hline 5 & 20 & 78.9 & 1 & 4.9 & 4 & 16.2 & 2.335329 & *58.07 \\
\hline 6 & 21 & 82.9 & 2 & 8.1 & 2 & 9 & 2.392216 & $* 83.40$ \\
\hline 7 & 17 & 70.7 & 5 & 22.5 & 3 & 6.9 & 2.637725 & $* * 221.54$ \\
\hline
\end{tabular}

* significant at $0.01 ; * *$ significant at 0.05 .

This section tapped the teachers' attitudes about culture in the current literature curriculum. Most English language and literature teachers showed positive attitudes towards culture teaching through literature.
In section 3 , which sought to identify methods of culture integration in EFL literature teaching in Saudi universities, the following table shows teachers' responses to the items of this section:

Table 3. Frequencies, percentages, weighted percentages, and $\mathrm{Chi}^{2}$ for teachers 'responses on section three of the questionnaire.

\begin{tabular}{llllllll}
\hline \multirow{2}{*}{ Items } & Agree & \multicolumn{3}{c}{ Neutral } & \multicolumn{2}{c}{ Disagree } & \multicolumn{2}{c}{$\begin{array}{l}\text { Weighted } \\
\text { percentage }\end{array}$} \\
\cline { 2 - 7 } & Freq & $\%$ & Freq & $\%$ & Freq & \% & Chi \\
\hline 9 & 10 & 40.4 & 11 & 44.9 & 4 & 14.7 & 2.257485 \\
10 & 12 & 50.0 & 6 & 24.4 & 7 & 25.6 & 2.248503 \\
11 & 14 & 56.0 & 5 & 19.8 & 6 & 24.3 & 2.314371 \\
12 & 18 & 71.6 & 5 & 21.0 & 2 & 7.5 & 2.640719 \\
\hline
\end{tabular}

* significant at $0.01 ; * *$ significant at 0.05 .

$\mathrm{The}_{\mathrm{Chi}}{ }^{2}$ values for the item analysis are significant at 0.01 as shown in Table 3. These values reveal that most of the teachers could use effectively recognized methods and techniques of culture education through the medium of literature in the undergraduate curriculum program. However, less than half the respondents did not agree or were neutral that they used these methods and techniques in using literature as a medium for culture and language education.

\section{Highlights from the Interviews}

In interviews with the 25 teachers in the survey study, most informants expressed their concern with the teaching of cultural aspects in language education implicitly or explicitly. While some few teachers said it was irrelevant or insignificant to dedicate parts of their teaching time and their teaching content to cultural education, this indicates that some of them are still uncertain about the need for culture in the language classroom.

Furthermore, the interviewees pointed out that literature courses and genres such as drama, poetry, short stories, novellas and novels, even those world classics translated into English could be "excellent sources of culture-laden material" for language learning. They further showed that excerpts, abridged works or full readers in these genres need to be deftly incorporated in the English literature courses of the undergraduate English program. Interviewed teachers said that novels and stories are rich with culture, and there should be more space for these courses across the language curriculum to replace the intensive language skills courses in the English program.

Interviewees further noted that the English language curriculum offered some sort of culture teaching but in meagre proportion to the language skills courses that are presented in the first two years in galore. So many interviewees were not convinced that enough culture learning occurred in the current English language curriculum. Interviewees further clarified that the literature courses are not satisfactory to provision for properly integrated culture learning. They said that some of the literature courses presented in the literature stream are typically readjusted to treat Islamic themes. Non-Saudi teachers expressed their caution that they could not teach any kind of literature lest they should be held accountable for teaching improper cultural content in these literature courses.

For the barriers to culture education in the literature stream, some teachers complained about the inconvenience of and inadequate access to suitable cultural content and teaching technology. Some said that the present literature courses do not offer them the chance to utilize videos for presenting novels, short stories or plays to their students in ways to effectively introduce the target culture in persuasive manners apposite to their learning styles. They also said that in some cases, the literary texts chosen for the literature syllabi cannot be integrated with audio-video material either because of unavailability of appropriate videos or time constraints. Further, the teachers said they did not incorporate even YouTube-available videos as supplementary material to these 
courses due to cultural barriers in Saudi Arabia, mostly ones that touch upon religious or socio-religious factors.

Interviewees also said that the Saudi culture of their students is more religiously and socially reserved than the English culture, which made it harder for them to integrate real-life aspects of the English culture. This shows that interviewees perceived the following elements as barriers or impediments to integrating culture within English literature teaching:

1. Native speakers with specialized knowledge in English or American literature are rare or nonexistent to teach the literature courses in the program;

2. There is not enough time nor sufficient material for teaching the cultural aspects of the literary texts introduced to the students;

3. There are some social and cultural as well as fanatically religious elements that impede spontaneous cultural elements in the English language program;

4. There is a shortage in teaching technology that can be adapted to culture learning in classrooms either due to lack of equipment or lack of copyright waivers.

Some teachers, however, believed that cultural content available within the present literature curriculum was good enough to teach culture through, and they did tend to teach culture through it. But they actually needed to plan their teaching beforehand. Ostensibly, teachers ought to plan parts of their courses more adaptively to address the target culture. The whys and wherefores are answerable by the cultural structure of the Saudi society. Many teachers said their students felt and expressed their feelings that some videos or even literary texts are culturally and religiously inappropriate for them to view.

In the interviews, teachers also thought it was problematic for them to teach overt and covert aspects of the English or American cultures. Overt cultural elements refer to visible elements and surface culture, while covert culture includes features that cannot easily be seen or understood. Levine and Adelman used an iceberg diagram to explain the concept, where the visible elements of culture include language, food, and attire, and most hidden features include beliefs, attitudes and values (p. xviii) [72]. Participating teachers tended to teach the overt cultural elements more often than the hidden ones, as they had little choice for teaching the covert culture, depending on the cultural content of literary texts.

\section{Conclusions}

The purpose of this study was to introspect the perceptions of teachers and their attitudes towards using literature courses in culture education in the foreign language classrooms in a Saudi university. The study emphasized the value of including culture in language learning, particularly in the literature stream of the curriculum. The researchers have reasoned that EFL professors in Saudi Arabia now realize the significant part that literature can play in culture learning in EFL courses at different levels.

The aim of this research was to pinpoint the perceptions and attitudes towards the role of literature courses in the teaching of culture in classrooms in the English program in a Saudi university, as entertained by teachers in the English department. The study highlighted the importance of integrating culture into language learning, especially in the literature curriculum stream. Findings assert that EFL teachers have already recognized the significant part that English literature plays in cultural teaching in EFL classes.

Furthermore, the interviewees expressed the need to integrate cultural educational content as part of their language teaching pedagogies either planned or spontaneously. Some of them said that some culture aspects are introduced, yet more casually than teaching other linguistic competences. This need has been consistently expressed in previous studies, suggesting that culture must be integrated in the language-learning program to complement the other linguistic competencies $[73,65,55,74,19,75]$. In this regard, Dirven and Putz [76], among several others, said that language teachers must include in their regular language teaching some aspects of cultural teaching [58-68].

In a similar fashion, ELT educators also need to develop new culturally-embedded curriculum and teaching approaches and methods intended to develop cultural learning in EFL students or at least adapt current syllabi and practices to include something about culture learning. In many instances, these amendments and adaptations will work towards enhancing intercultural communication competences as well as remove impediments and barriers to culture teaching of the literature courses.

\section{Further Research}

Further research is advocated to explore the pedagogies of culture teaching with large-sized samples. Introspective research for examining the views of native speakers and nonnative speakers as regards culture education can provide expedient teaching models or inform the development of culturally sensitive textbooks that would enhance TEFL in Saudi Arabia.

Additional research is also needed to see if there is a direct link between openness to cultural and linguistic patterns and the ability to learn a second or foreign language. Such a link may be particularly important at a time when the nature of intercultural competence is receiving a lot of attention at the international level. As a result, new methods of evaluation and investigation will be needed to gather data to explore the effects of increased learning of EFL and overall ELT curriculum development. One approach would be to examine the relationships between language learner openness and different cultural perspectives and their progress in second/foreign language acquisition / learning.

\section{Funding}

This paper was funded by the deanship of Academic Research, King Khalid University as part of a research group project No 250 . 


\section{Appendix}

\section{Appendix A. The Questionnaire on Culture in the EFL Classroom}

The purpose of this questionnaire is to introspect the perceptions of and attitudes toward whether and how literature could be used as a teaching medium for the target culture by teachers of EFL for EFL college majors. The researchers honestly appreciate your support in filling out this survey. You may add more detail or comments below:

Demographic information

Previous and current affiliation

University

Junior college

other

Number of years of teaching experience

Course information

Average number of students in your English courses

Main skill focus (es) of the courses you teach (circle a maximum of three)

- Speaking - Listening - Reading - Writing - Multi-skill

Table A1. Culture Integration in the EFL Classroom.

\begin{tabular}{|c|c|c|c|c|c|}
\hline & 1 & 2 & 3 & 4 & 5 \\
\hline \multicolumn{6}{|l|}{ Culture Content in Literature Courses } \\
\hline \multirow{2}{*}{\multicolumn{6}{|c|}{$\begin{array}{l}\text { It is important for EFL teachers to include aspects of the target language's culture in the literature and language } \\
\text { courses I give. Literature gives clues about the target culture. } \\
\text { I take every opportunity to integrate literature-based cultural material related to the English language culture in my } \\
\text { EFL classes even if there is no direct relationship to the lessons. } \\
\text { The cultural content in literature courses is sometimes planned and sometimes spontaneous, depending on the } \\
\text { relevance to the lessons. } \\
\text { The cultural content in language skills and literature courses includes information related to factual/overt culture, e.g. } \\
\text { food, music, people, or implicit aspects about metalanguage, i.e., gestures, facial expressions, body language, etc. }\end{array}$}} \\
\hline & & & & & \\
\hline \multicolumn{6}{|l|}{ Attitudes towards Culture Teaching } \\
\hline \multicolumn{6}{|l|}{$\begin{array}{l}\text { I like to incorporate information related to covert culture, e.g. values, beliefs, attitudes, ethics, body language, etc. in } \\
\text { the language curriculum. } \\
\text { I am curious to introduce cultural aspects where English diverges from Arabic, e.g. greetings, shake-hands, use of } \\
\text { first/last names, giving/responding to compliments, etc. } \\
\text { I am interested in explaining wider aspects of (in) appropriate behavior or ways of talking in the target culture that } \\
\text { differ in English and Arabic. }\end{array}$} \\
\hline \multicolumn{6}{|l|}{ Methods and Techniques in Culture Teaching } \\
\hline $\begin{array}{l}\text { At times, when there is a chance, I provide contrastive cultural examples that show the difference between Arabic and } \\
\text { English. } \\
\text { I provide excerpts of literary texts that include culturally-laden vocabulary. } \\
\text { I discuss new words and meanings in literary texts to introduce the cultural usages of this vocabulary. } \\
\text { Literary texts including dramatic characters or narratives can be used where students can make use of the dialogs in } \\
\text { their daily lives. }\end{array}$ & & & & & \\
\hline
\end{tabular}

\section{Appendix B. Interviews Script}

Are you concerned with the teaching of language skills only without introducing cultural differences in language use either in English dialects, e.g., British English versus American English or between Arabic and English?

Does the language skills curriculum in your English program provide sufficient cultural teaching for your students? Are these cultural aspects found in the published texts that you use?

What are the barriers that impede cultural teaching for promoting language learning?

How do you feel about the quality of cultural content in the textbooks of the English language program in your college?

Comments: 


\section{References}

[1] Citron, J. (1995). Can Cross-Cultural Understanding Aid Second Language Acquisition? Toward a Theory of EthnoLingual Relativity. Hispania, 78 (1), 105-113.

[2] Brooks, N. (1969). 'Teaching Culture in the Foreign Language Classroom', Foreign Language Annals, 2.3: 304-09.

[3] Brooks, N. (1975). The analysis of foreign and familiar cultures. In Lafayette, R. (ed.). The Culture Revolution in Foreign Language Teaching. Skokie, Illinois: National Textbook Company.

[4] Brooks, N. (2008). Teaching Culture in the Foreign Language Classroom. Foreign Language Annals, 1 (3): 204-217. DOI: 10.1111/j.1944-9720.1968.tb00135.x.

[5] Harumi, I. (2002). A New Framework of Culture Teaching for Teaching English as a Global Language. RELC Journal, 33 (2), 36-57.

[6] Ilieva, R. (2005). A story of texts, culture (s), cultural tool normalisation, and adult ESL learning and teaching. Unpublished Ph. D., Simon Fraser University.

[7] Deters, F. (2009). Identity, agency, and the acquisition of professional language and culture: the case of internationally educated teachers and college professors in Ontario. Unpublished $\mathrm{Ph}$. D. Ontario Institute for Studies in Education of the University of Toronto.

[8] Sun, L. (2013). Culture Teaching in Foreign Language Teaching. Theory and Practice in Language Studies, 3 (2) pp. 371-375. doi: 10.4304/tpls.3.2.371-375.

[9] Nostrand, H. L. (1967). A Second Culture: New Imperative for American Education. In Michel, J. Foreign Language Teaching. An Anthology. London: Collier-MacMillan.

[10] Lessard-Clouston, M. (1997). Towards an Understanding of Culture in L2/FL Education. In Ronko, K. G. Studies in English, 25, 131-150: Kwansei Gakuin University Press.

[11] Hall, E. T. (1981). The Silent Language. New York: Anchor Books.

[12] Nostrand, H. L. (1974). Empathy for a second culture: Motivations and techniques. In Jarvis, G. A. (ed.). 1974. Responding to New Realities. ACTFL Foreign Language Education Series, vol. 5. Skokie, Illinois: National Textbook.

[13] Seelye, H. (1984). Teaching culture: Strategies for intercultural communication. Revised edition. Lincolnwood, IL: National Textbook Company.

[14] Seelye, H. (1974). Teaching culture: Strategies for foreign language educators. Skokie, IL: National Textbook Company.

[15] Kramsch, C. (1993). Context and Culture in Language Learning. Oxford: Oxford University Press.

[16] Oxford, Rebecca (2001). Integrated Skills in the ESL/EFL Classroom. ERIC Digest. ERIC Digests: ED456670.

[17] Tucker, G. R., and Lambert, W. E. (1972). Sociocultural Aspects of Foreign-Language Study. In J. W. Oller \& J. C. Richards (eds.). Focus on the learner (pp. 240-259). Roawly, MA: Newbury House.
[18] Humphrey, D. (1997). Integrating Intercultural Training Material in the ELT Classroom. Proceedings of the conference at Leeds Metropolitan University, 15-16 December 1997.

[19] Valdes, J. M. (1995). Culture bound (2 ${ }^{\text {nd }}$ ed.). New York: Cambridge University Press.

[20] Lessard-Clouston, M. (1996). Chinese teachers views of culture in their EFL learning and teaching. Language, Culture and Curriculum, 9 (3), 197-224.

[21] Prodromou, L. (1992). What culture? Which culture? Crosscultural factors in language learning. ELT Journal, 46 (1), 3950 .

[22] Duff, Patricia A.; Uchida, Yuko (1997). The Negotiation of Teachers' Sociocultural Identities and Practices in Postsecondary EFL Classrooms. TESOL Quarterly, 31 (3), 451-86.

[23] Arries, J. F. (1994). 'Constructing Culture Study Units: A Blueprint and Practical Tools', Foreign Language Annals 27.4 523-34.

[24] Bragaw, D. H. (1991). 'The Global Imperative and its Metalanguage', Foreign Language Annals, 24.2: 115-23.

[25] Damen, L. (1987). Culture learning: The fifth dimension in the language classroom. Reading, MA: Addison-Wesley.

[26] Hadley, A. O. (1993). 'Teaching for Cultural Understanding', in A. Hadley (ed.), Teaching Language in Context (Boston: Heinle \& Heinle): 357-406.

[27] Mantle-Bromley, C. (1993). Preparing Teachers to Make a Global Difference. Foreign Language Annals, 26.2: 208-16.

[28] Bessmertnyi, A. (1994). Teaching Cultural Literacy to Foreign-Language Students. English Forum, 32: 1.

[29] Amin, N. (1997). Race and the identity of the nonnative ESL teacher. TESOL Quarterly, 31 (4), 580-583.

[30] Kachru, B. B. (ed.) (1992). The Other Tongue: English across Cultures, $2^{\text {nd }}$ edn, Urbana: Illinois University Press.

[31] Kirkpatrick, A., Patkin, J. and Wu, J. (2013) "The Multilingual Teacher and the Multilingual Curriculum: An Asian Example of Intercultural Communication in the New Era," in F. Sharifian and M. Jamarani (eds) Intercultural Communication in the New Era, London: Routledge, pp. 263288.

[32] Schneider, E. (2007) Postcolonial English: Varieties around the World, Cambridge: Cambridge University Press.

[33] Schneider, E. (2010) "Developmental Patterns of English: Similar or Different?," in A. Kirkpatrick (ed.) The Routledge Handbook of World Englishes, London: Routledge, pp. 372384.

[34] Valdes, J. M. (ed.). (1986). Culture Bound: Bridging the Cultural Gap in Language Teaching. Cambridge: Cambridge University Press.

[35] Wee, Lionel. (2002). When English is Not a Mother Tongue: Linguistic Ownership and the Eurasian Community in Singapore. Journal of Multilingual and Multicultural Development, 23: 282-295. 
[36] Kachru, B. B. (1985). Standard, Codification and Sociolinguistic Realism: The English Language in the Outer Circle," in R. Quirk and H. Widdowson (eds) English in the World: Teaching and Learning the Language and Literatures, Cambridge: Cambridge University Press, pp. 11-30.

[37] Kachru, B. B. (1984). Thealchemy of English: Social and functional power of non-native varieties. In C. Kramarae, M. Schulz, \& W. M. O’ Barr (Eds.), Languageandpower (pp. 176193). Beverly Hills, CA: Sage.

[38] Ting-Toomey, S. and Kurogi, A. (1998), "Facework competence in intercultural conflict: an updated facenegotiation theory", International Journal of Intercultural Relations, 22 (2), pp. 187-225.

[39] Lafayette, Robert C., Schulz. R (eds.). (1975). TheCultural Revolution in Foreign Language Teaching. A Guidefor Building the Modern Curriculum. USA: National Text Book Company.

[40] Byram, M. and Wagner, M. (2018). Making a di erence: language teaching for intercultural and international dialogue.', Foreign language annals, 51 (1). pp. 140-15.

[41] Petersen, A., Bente, G., \& Krämer, N. C. (2002). Virtuelle Stellvertreter: Analyse avatar-vermittelter Kommunikationsprozesse. In G. Bente, N. C. Krämer, \& A. Petersen (Eds.), Virtuelle Realitäten (pp. 227-253). Göttingen, Germany: Hogrefe.

[42] Coperías-Aguilar, María José (2010). Intercultural Communicative Competence as a Tool for Autonomous Learning. Revista Canaria de Estudios Ingleses 61: 87-98.

[43] Balboni, P. E \& Caon, F. A. (2014). Performance-oriented Model of Intercultural Communicative Competence, Venice. Journal of Intercultural Communication, Issue 35, July 2014 http://www.immi.se/intercultural/nr35/balboni.html.

[44] Cushner, K. McClelland, A. \& Safford, P. (2014). Human Diversity in Education. $8^{\text {th }}$ ed., McGraw-Hill Education.

[45] Schieffelin, B. B., \& Ochs, E. (Eds.). (1986). Studies in the social and cultural foundations of language, No. 3. Language socialization across cultures. Cambridge University Press.

[46] Garret, P. \& Baquedano-Lopez, P. (2002). Language Socialization: Reproduction and Continuity, Transformation and Change. Annual Review of Anthropology, 31, pp. 339-361.

[47] Liu, J. (2009). Students' construal of intercultural communication competence and intercultural communication teaching. Intercultural Communication Studies, 18 (2), 92.99.

[48] Liu, S., Volcic, Z. \& Gallois, C. (2014). Introducing Intercultural Communication Global Cultures and Contexts. Sage.

[49] Alptekin, C. (2002). Towards intercultural communicative competence in ELT. ELT journal, 56 (1), 57-63.

[50] Arevalo-Guerrero, E. (2009). Assessing the development of learners' intercultural sensitivity and intercultural communicative competence: The intercultural Spanish course. University of Maryland, Baltimore County.

[51] Chen, G. M., \& Young, P. (2012). Intercultural communication competence. In A. Goodboy \& K. Shultz (Eds.), Introduction to communication: Translating scholarship into meaningful practice (pp. 175-188). Dubuque, IA: Kendall-Hunt.

[52] Bhawuk, D. P. S., \& Brislin, R. (1992). The measurement of intercultural sensitivity using the concepts of individualism and collectivism. International Journal of Intercultural Relations, 16 (4), 413-436.

[53] Paige, R. Michael, ed. (1993). "On the Nature of Intercultural Experiences and Intercultural Education." In Education for the Intercultural Experience, ed. R. Michael Paige. pp. 1-19. Yarmouth, Maine: Intercultural Press.

[54] Bennett, J. M., \& Bennett, M. J. (2003). Developing intercultural sensitivity: An integrated approach to global and domestic diversity. In D. Landis, J. M. Bennett, \& M. J. Bennett (Eds.), Handbook of Intercultural Training ( $3^{\text {rd }}$ ed., pp. 1-10). Thousand Oaks, CA: Sage.

[55] Kramsch, C. (1998). Language and culture. Toronto: Oxford University Press.

[56] McLeod, B. (1976). The Relevance of Anthropology to Language Teaching. TESOL Quarterly 10 (2): 211-20.

[57] Cai, M. (2002). Multicultural Literature for Children and Young Adults. Reflection on Critical Issues. Westport Conn.: Greenwood Press.

[58] Cegala, D. J., McGee, D. S., \& McNeilis, K. S. (1996). Components of patients' and doctors' perceptions of communication competence during a primary care medical interview. Health Communication, 8 (1), 1-27.

[59] Crawford, C. L., Omery, A., \& Seago, J. A. (2012). The challenges of nurse-physician communication: A review of the evidence. Journal of Nursing Administration, 42 (12), 548550 .

[60] Crawford, T., Candlin, S., \& Roger, P. (2015). New perspectives on understanding cultural diversity in nursepatient communication. Collegian, 24 (1), 63-69.

[61] Delgado, D. A., Ness, S., Ferguson, K., Engstrom, P. L., Gannon, T. M., \& Gillett, C. (2013). Cultural competence education for clinical staff measuring the effect of a one-hour class on cultural competence. Journal of Transcultural Nursing, 24 (2), 204-213.

[62] Divi, C., Koss, R. G., Schmaltz, S. P., \& Loeb, J. M. (2007). Language proficiency and adverse events in US hospitals: A pilot study. International Journal for Quality in Health Care, $19(2), 60-67$.

[63] Elderkin-Thompson, V., Silver, R. C., \& Waitzkin, H. (2001). When nurses double as interpreters: A study of Spanishspeaking patients in a US primary care setting. Social Science \& Medicine, 52 (9), 1343-1358.

[64] Fatahi, N., Mattsson, B., Lundgren, S. M., \& Hellström, M. (2010). Nurse radiographers' experiences of communicating with patients who do not speak the native language. Journal of Advanced Nursing, 66 (4), 774-783.

[65] Finke, E. H., Light, J., \& Kitko, L. (2008). A systematic review of the effectiveness of nurse communication with patients with complex communication needs with a focus on the use of augmentative and alternative communication. Journal of Clinical Nursing, 17 (16), 2102-2115.

[66] Stephens, K. (1997). Cultural stereotyping and intercultural communication: working with students from the People's Republic of China in the UK. Language and Education, 11, 113-124. 
[67] Uzun, O., \& Sevinc, S. (2015). The relationship between cultural sensitivity and perceived stress among nurses working with foreign patients. Journal of Clinical Nursing, 24 (23-24), $3400-3408$

[68] Satu, K. U., Leena, S., Mikko, S., Riitta, S., \& Helena, L. K. (2013). Competence areas of nursing students in Europe. Nurse Education Today, 33 (6), 625-632.

[69] Mohammadzadeh, B. (2009). Incorporating multicultural literature in English language teaching curriculum. Paper presented in the proceedings of the World Conference on Educational Sciences, Nicosia, North Cyprus, 4-7 February 2009 -New Trends and Issues in Educational Sciences, published in Procedia -Social and Behavioral Sciences, vol. 1, issue 1, pp. 23-27.

[70] Gall, M., Borg, W. \& Gall, J. (1996). Educational research: an introduction (6th ed.). New York, Longman.

[71] Patton, M. Q. (2002). Qualitative research \& evaluation methods. $3^{\text {rd }}$ ed. Thousand Oaks, CA: Sage Publications.
[72] Levine, D. R. and Adelman, M. B. (1993). Beyond Language. Englewood Cliffs, NJ: Prentice-Hall Regents.

[73] Byrnes, H. (1991). Reflections on the development of crosscultural communicative competence in the foreign language classroom. In B. Freed (Ed.), Foreign language acquisition research and the classroom (pp. 205-218). Lexington, MA: D. C. Heath and Company.

[74] McGilton, K., Irwin-Robinson, H., Boscart, V., \& Spanjevic, L. (2006). Communication enhancement: Nurse and patient satisfaction outcomes in a complex continuing care facility. Journal of Advanced Nursing, 54 (1), 35-44.

[75] Yilmaz, M., Toksoy, S., Direk, Z., Bezirgan, S. \& Boylu, M. (2017). Cultural Sensitivity Among Clinical Nurses: A Descriptive Study. Journal of Nursing Scholarship, 49 (2), 153-161. doi: https://doi.org/10.1111/jnu.12276.

[76] Dirven, R., \& Putz, M. (1993). Intercultural communication. Language Teaching, 26, 144-156. 